\title{
Organization as process: Drawing the line between endogenous and exogenous views
}

\begin{abstract}
This paper attempts a typification of processes views in organization studies. As a basis for our analysis, we assume that distinctions may be drawn is the way that entities are conceptualised in the analysis, what we refer to as the process of “entification”. From this point of departure we explore four different process views, namely: process as flows, process as programmes, process as recursive reproduction and process as connectivity. The first two views; process as flows and process as programmes tend to build on the assumption that the processes take place within relatively stable entified contexts, such as the organization or the institutional environment. This we refer to as an "exogenous" view. A second set of views of process is what we refer to as "endogenous" views. These two views are what we call endogenous, as they assume that entification resides in the process itself.
\end{abstract}




\section{Introduction}

Recent writings in organization studies suggest that the implications of process thinking are substantial and that they recast central notions of organizational change and stability. It is timely, however, to look more closely at what distinguishes process approaches in the study of organization. The paper shows that views vary considerably. As a basis for our analysis, we assume that distinctions may be drawn is the way that entities are conceptualised in the analysis, what we refer to as the process of "entification". From this point of departure we explore four different process views in organization theory, namely: process as flows, process as programmes, process as recursive reproduction and process as connectivity. Each of these views reflects a different way of placing the locus of entification in relation to processes. The first two views; process as flows and process as programmes tend to build on the assumption that the processes take place within relatively stable entified contexts, such as the organization or the institutional environment. This we refer to as an "exogenous" view. A second set of views of process is what we refer to as “endogenous” views. These two views are what we call endogenous, as they assume that entification resides in the process itself. In our conclusion, we question whether the two types of views are not reducible to one another; that they are analytically irreconcilable approaches.

The roots of process thinking go back to Greek and Roman philosophers and have been pursued in different ways by modern philosophers (e.g. Whitehead, 1929; Bergson, 1988; James, 1996) writers in sociology (e.g. Luhmann, 1995; Elias, 1970), science and technology studies (e.g. Latour, 1987, 1995), and organization (e.g. Cooper, 1976; Weick, 1979; Chia, 1999; Tsoukas and Chia, 2002; Law, 1994, 2004; Styhre, 2004). Process thinking has always been subjected to differences in interpretation, which can be traced in social science and organization studies. In the early Greek philosophers’ arguments over nature and reality there is a split between the idea of the world as flow and as substance. Heraclites, subscribing to the world as consisting of basic substances (air, water, earth and fire), argued that nothing really ever stays the same. Parmenides on the other hand, insisted upon the permanent and unchangeable nature of things. This sort of dichotomy has been a feature of 
philosophical debate. In organization studies, Chia (1999), for example, suggests that ever since, the history of Western thought has, therefore, been little more than a continuing series of footnote attempts at synthesizing these two great but apparently irreconcilable intellectual traditions, where one constitutes an "entitative” conception of reality, and the other emphasizing an inclusively processual view. In a similar vein, Van de Ven and Poole (2005) draw a distinction between Heraclites' and Parminides' views. Van de Ven and Poole in particular draw a parallel between such distinctions in philosophy and perspectives in organization theory, suggesting that Heraclit reflects a "process view” and Parmenides a "variance view”.

Such distinctions, we argue, may serve as backdrops to philosophical debates about the nature of things. However, such distinctions tend to be too coarse to be of much help to organization studies. A field such as organization studies, leaves a number of options open for how process is conceptualised. It offers - indeed obliges - choices to be made about what to consider the very objects of process. Put simply, what we consider as entity and what we consider as flow. This paper aims to develop some types of processes thinking relevant to organization studies, and suggests a mapping serving as a preliminary typology.

Although a number of works debate the nature of process views and their implications for organization and management theory (i.e. Pettigrew, 1987, 1997; Weick, 1979; Chia, 1999; Tsoukas and Chia, 2002; Van de Ven and Poole, 2005; Bakken and Hernes, 2006), there is often not a clear distinction between the different understandings of process. With some exceptions (e.g. Tsoukas and Chia, 2002; Van de Ven and Poole, 2005; Hernes, 2007) the word "process" is used merely to underline that movement is taken into consideration. Sometimes a processual twist is performed merely verbally, such as by replacing strategy with “strategizing”, drawing inspiration from Weick's urge to replace organization with organizing. Such attempts serve to sensitize readers to the idea that nothing ever really stays the same. However, adding”-ing" to a noun, as much as it turns it into a verb in linguistic terms, does not do much to the ways that we actually conceptualize process and how we formulate all the important questions that come with that conceptualization.

A review of works of process writers would suggest that a decisive question for analysis would relate to how stability of entities is treated in the analysis. Weick 
(1979) delivered an early attack at the assumption of organizations as noun like entities. Weick's argument was that we are better off replacing nouns with verbs, replacing the noun “organization” with the verb “organizing”. As useful as Weick's argument was then, a separation between process and entity upholds dichotomy rather than contribute towards nuancing (Bakken and Hernes, 2006). We have pointed briefly above to the polarization of views inherited from the debate between Greek philosophers. It is time, however, to substantiate types of "entification" that apply to different forms of organizational analysis. By "entification” we mean the extent to which something is seen to exist in itself, independently of its relations with others. An entity is not to be taken as analogous to a physical object, although it may also be a physical object. An entity is something that is delimited and recognised as something that can be talked about, such as a concept, a company, a technology, a person or a group of people.

As mentioned above, we do not think that the process versus entity distinction, although it is justifiable as a philosophical backdrop of analysis, is sufficiently fine grained for interpreting the process aspect of organizational analysis. There is no "natural” split between process and entity. What we tend to consider entities, such as humans, artefacts, technologies and organizations, may be seen to become what they “are” through processes. Human actors in organizations may well be considered to be in the process of becoming something else than what they are at present. Czarniawska (1997, 2004), for example, makes the point that there must be something that precedes the making of actors, and that is actions. In other words, actors, to the extent that they are seen as entities, become "entified” though the actions they perform, which confers identity upon them. Hence, entification is a matter of degree and type rather than an absolute state. Rather than ask whether something is process or entity, the question to ask is what is allowed to change, and what is considered stable? Once we consider any "thing” in the analysis, "its" change may be considered possible to a smaller or lesser degree. To take an example, if we wish to analyse the process of a manager taking over an organizational unit, it may be necessary to ask the question whether the manager "is" is the same after having worked with the materials as (s)he was at the beginning. He or she may enter the unit with ideas and plans for change, 
but as (s)he performs her (his) role as manager, the unit (and the surrounding organization) will have affected the manager in turn.

In this paper we suggest that a significant distinction resides in the difference between an exogenous and an endogenous view of process. According to an exogenous view, processes are framed by factors exogenous to them, such as for example organizational boundaries. By implication, processes can be interpreted in relation to something stable and external to them. The locus of entification of an exogenous view lies in the context external to the process. According to an endogenous view, on the other hand, processes are interpreted in relation to themselves, as external, stable, factors are not assumed to frame the process According to the latter view, that which becomes the subject of entification resides in the process itself, and not to entities in the external environment.

\section{An exogenous view of process}

An exogenous view of process suggests that the process, i.e. that which moves, is interpreted in relation to something outside the process, what we might call the context for the process. For example, when processes are identified within an organization the processes themselves account for anticipated movement within the organization's boundaries. From this perspective, the organization forms the context, inside which the movement takes place. The actual patterns of movement reflect what the identity of the organization can be said to be, such as, for example bureaucratic organizations being traditionally associated with rule-based behaviour, formal plans and relatively little movement of people across functional borders. What then constitutes organizational change, is change in the internal patterns of flows or programmes. If, for example, informal communication takes over from formal communication, one could say that the organization has changed towards a more informal culture of communication. This is typically the view taken by Pettigrew (1987) and Pettigrew, Woodman and Cameron (2001:700): 
"If the change process is the stream of analysis, the terrain around the stream that shapes the field of events, and is in turn shaped by them, is a necessary part of the investigation."

In this quote, they refer to the "terrain" rather than the context, the terrain being that which surrounds the stream. Analytically, this means that if we allow the process to change, the organization surrounding the process is assumed to stay pretty much the same. If we were to allow the terrain (or, for example, the boundaries) to change, there would be little against which to make sense of the process.

A number of different schools in organization and management theory operate with context as the determining factor for processes. An exogenous view is central to important schools in organization theory over the last few decades, such as organizational ecology (Hannan and Freeman, 1989), new institutionalism (DiMaggio and Powell, 1983, 1991), resource dependence theory (Pfeffer and Salancik, 1978), evolutionary organization theory (Aldrich, 1999) and economic sociology and business systems (Morgan, Whitley and Moen, 2005). The main thinking behind these schools is that the character of processes within organizational boundaries are the way they are because they respond to factors in the external environment of the organization. Processes fit in with their external environments, such as by adopting structures that are deemed legitimate and timely, which is a tenet of new institutional theory. This is why in new institutionalism, for example, forces such as imitation and coercion are seen as strong influences in the adoption of management ideas. The sources of both imitation and coercion are located outside the organization. For those who are less interested in the symbolic side of adaptation, and more interested in economic performance, external criteria, such as competition and regulation replace the influence of norms and needs for legitimacy. There is a huge literature on business performance that aims to understand how competition works as a mechanism of selection on the basis of performance. There are similar examples in some of the management theory, such as where the adoption of certain management styles are seen to correlate successfully with certain types of problems.

In what follows we distinguish two view that we see as typically exogenous in organization studies. The first - process as flows - represents a broad range of flows 
that may take place within organizational boundaries. In a sense, process as flows includes any, flow, intended or unintended, physical or human that makes up the organization. Process as programmes - the second type of process - consists of regularized chains of actions designed intentionally to solve problems facing the organization. Because programmes are intentional they make up what is commonly referred to as the formal part of an organization.

\section{Exogenous view 1: Process as flows}

In organization and management studies process tends to be taken as a general term describing anything that flows as opposed to remaining static. Flows of labour, operations, transactions, materials and information have been studied as processes since before Weber's time, which is a date that is taken by several writers as the genesis of organization theory. Take, for example, the following extract from Adam Smith’s ([1776]1986:110) Wealth of nations, written a century before Weber:

"One man draws out the wire, another straights it, a third cuts it, a fourth points it, a fifth grinds it at the top for receiving the head; to make the head requires three distinctive operations; to put it on is a peculiar business, to whiten the pins is another; it is even a trade by itself to put them into the paper; and the important business of making a pin is, in this manner, divided into about eighteen distinct operations, which, in some manufactories, are all performed by distinct hands, though in others the same man will perform two or three of them."

If counted in their smallest units, the amount of flows is potentially infinite in any given organization. In an average sized company or public administration, for example, thousands of emails may be composed, sent, received, opened, read and acted on every day. Flows are not associated with physical entities alone. Weick's (1995) review of the sensemaking literature, for example, suggests how flows of impressions, interpretations and enactment constitute the day to day life in organizations: 
"The processes themselves are also streams. They are social, and they involve multiple actors. The outcomes of organizing are reasonable interpretations of a slice of experience; these slices are treated as being amenable as well as prescriptive for future activities. Thus processes are assembled from flows, directed at flows, and summarize flows”. (Weick, 1979:47)

Although the number and variations between flows are substantial, there are inevitably features of the flows that are fairly coherent, and the features of the flows in an organization serve to distinguish it from other organizations.

Flows are largely assumed to constitute the "fluid stuff" that relates to the functioning of the organization, implying that organizations serve to form contexts, or spaces, (Hernes, 2004) within which flows take place. Hence, most studies regard flows as being contextualized by the organization, where the form of the organization influences the type of flows that takes place. In their study, Burns and Stalker (1961), for example distinguished between so-called "mechanistic" organizations relying more on formal communication and "organic" organizations where informal communication was more of the order of the day. Thus, dominant or recurring features of the flows that exist in an organization confer identity upon that particular organization. When processes are studied as flows, it is assumed that their context represents a relatively entity against which the flows are interpreted. For example, a high degree of market orientation of organization's internal communication may be held up against a number of different characteristics of the external environment, such as choosy and conscientious customers. In this case, entification lies with customers, who are perceived as entities with certain attributes, such as choosy or conscientious.

Analysis of flow normally assumes a locus of entification beyond the level of the flow, which is the context for the flow. The context tends to be considered a different level from the flow, such as a department, for example, being seen as the context for the behaviour of staff belonging to that department. In this case, the entity is the department, with its "box" on the organizational chart, with the diverse flows going on within it or across the borders with other departments. The "box", however, belongs at a different level of analysis from the actual flows. Analytically this implies 
that the two (the flows and the department) are considered at separate level, where the context influences what goes on. However, the reverse is not equally true, which mans that flows are not considered to impact on the department level. An implication is that the context for flows is entified, and thus little sensitive to being influenced by the flows.

Exogenous view 2: Process as programmes.

Programmes constitute the more formalized patterns of organizational problem solving that serve to distinguish one organization from another. Whereas flows, as discussed above, may be associated with a broad range of things, including technologies, humans or sensemaking; programmes entail programmed activity. In their pioneering work, March and Simon (1958) evoked the idea of programmes, which they saw as constitutive of formal organizations. March and Simon (1958) drew a distinction between procedural and substantive programmes, where procedural programmes aim at the structure of the problem solving process while substantive programmes are aimed at the structure of the problem itself. Essentially, programmes, whether procedural or substantive, are structured sets of activities. They perform according to some predefined structure in order to solve problems. In other words, they are formed in anticipation, either to solve problems that exist or problems that may arise.

Programmes constitute largely what is commonly referred to as formal organization. Programmes serve both to uphold formal organizations in stable states as well as changing them. Programmes are processes in the sense that they consist of programmed connected bits and pieces of actions that connect logically, based on some idea about how the organization should stabilise or change. They represent formal organization because they are formalized in the way of being tangible sets of activities belonging exclusively to the organization in question, defined mainly by organization leaders. Hence, programmes are constitutive of "formal" identity of the organization, while at the same time serving as problem solving mechanisms. This double feature of programmes is illustrated in Hernes and Schjelderup's (2005) study of a Norwegian dairy co-operative. The co-operative is owned by dairy farmers, who 
exercise their ownership through votation at an annual meeting gathering hundreds of farmer representatives. The annual meeting is clearly a "programme”, being a set of programmed sets of actions, which is part and parcel of the co-operative's decision making processes. The farmers vote on strategic issues that are of relevance to their level of ownership. At the same time, the event is an important identity creating ritual, reinforcing the idea of cooperative ownership.

Examples of programmes aimed at organizational change are found in studies of reform in the public sector (e.g. Brunsson and Olsen, 1990), which is launched in the form of programmes with the aim of changing organizational arrangements away from status quo and towards some predefined set of goals. Reform programmes are unique sets of activities that are launched to solve non-standard problems. Another type of programme is routines (Feldman, 2000), which are generalized programmes to deal with standard problems. For example, routines for hiring and firing people are established because these are problems that are recurrent for organizations.

Various works illustrate how programmes arise and are adopted as practices in organizational fields (Dimaggio and Powell, 1983), which means that they become constitutive of organizational identity on the particular fields of which they form part. Feldman and Pentland (2005), for example, suggest how organizations actually come to evolve around routines that are distinct for a field of organizations, how they in fact become the building blocks of both organizations and organizational fields. The adoption of certain programmes, such as routines, relies on the search of for a collective identity, hence, the need for legitimacy. Behind much thinking about programmes thus lies the assumption that they arise out of the demands from a context that lies outside the program, either as a way of rationalizing activities or as way to build organizational identity.

It should be noted that although programmes may be considered to be rooted in logical coherence, that does not imply that the consequences of implementing programmes are consistent with expectations. In fact, as shown in the reform literature (e.g. Brunsson and Olsen, 1990), intended programmes may not even be implemented as planned. Although programmes may arise from a coherent set of ideas and aimed at preserving stability, they may sometimes lead to the opposite, similar to what Merton (1936) referred to as the unintended consequences of 
purposive social action. This does not undermine the character of formal organizations, since, in the words of March (1981) they are essentially incoherent systems operating in an incoherent world.

The coherence that March alludes to, may be found in the entification of programmes. Programmes take on labels, such as for example "Total quality”, or "Process re-engineering", which allows them to be talked about and implemented as packages of internally coherent sets of actions, each "package” bearing promise of a different impact on the organization. Much the same goes for routines, which, once they are recognized as exhibiting some uniqueness, can be adopted by organizations elsewhere. The naming of programmes under labels confers upon them an entitative status, because it is the entitative status which makes them recognisable. Entitative status also makes programmes available for assessment and evaluation, something which enables them to be analysed from the perspective of cause and effect. It is within a logic of cause and effect that studies of reform programmes, for example, have been conceived, which allows writers such as Brunsson (2005) and Brunsson and Olsen (1989) to question the success of many reform programmes, particularly in the public sector. A similar logic can be seen in writings on routines, where Feldman (2000), for example, suggests conditions under which routines may lead to organizational change. Feldman points out three reasons why routines change through emergent processes. One reason is that unintended outcomes are produced. Another reason is that new problems arise that need to be solved. A third reason is that new resources are produced, creating new opportunities. An example of the latter is when new knowledge is produced, enabling innovation of new products or procedures. It is notable that in each of the three cases, change is related to what the routine is expected or not expected to accomplish. Hence, the routine is considered a package that can be held up against the effects it has on problem solving.

Whether we are talking about programmes of reform or routines, they are both entifications of processes. Programmes and routines contain actions, which constitute the actual process. When programs or routines are abstracted from their contexts, they are done so by virtue of labels bearing promise of certain qualities. Thus the processes of actions are subsumed under entified labels. When programs or routines are transpoert to other contexts, they are adopted on the basis of comparison with 
stable characteristics of their "new" context, such as organizational goals, vision, structure and resources.

\section{An endogenous view of process}

In the case of an exogenous view, the basis from which analysis is carried out, is the outer context, the outer limits that we assume to frame the processes and to give them their form. Exogenous factors tend to support processes, give them a "home" so to speak. If exogenous factors are not taken as a basis, however, the "basis" of analysis resides in the process itself; the process becomes its own rationale, so to speak. In the absence of exogenous factors, the process interacts with itself, with its past which is carried forward into a relatively stable basis for further processes. The shift of focus from the exogenous is decisive for analysis, both for carrying out the analysis and for the type of arguments resulting from the analysis.

Weick’s (1979) early work is an example of how a clear distinction may be drawn between exogenous and endogenous analysis. Weick is well known for introducing the learning loop of enactment - selection - retention. The model was inspired by Campbell's (1969) variation-selection-retention model of sociocultural evolution (note the difference). Campbell's work, however, assumed exogenous selection in evolution, meaning that systems were "selected" by their external environments. Weick, on the other hand, replaced Campbell's 'variation' with 'enactment' to emphasize the active role organizational members play in creating, defining, giving meaning to, and influencing their environments. Weick's departure is highly significant largely because it shift focus from how a state of organization correlates with its context to focus on how a state of organization actually comes about through processes of enactment. These processes of enactment come from within the organization rather than from the outside.

\section{Endogenous view 1: Process as connectivity}

From the perspective of process philosophy Whitehead (1938:9) held that “connectedness is of the essence of all things of all kinds”. Connectedness implies 
basically the readiness for various heterogeneous elements to interact and thus create a coherent whole. It has been discussed how an exogenous view treats organizations or environments as contexts for interaction. A different view is pursued by an emerging group of theorists, who seek to transcend limits of organizational theorizing by seeing organization as the process of connecting of heterogeneous elements. Their conceptualization shows how organizations unfold from a more eclectic basis of factors, such as artefacts, technologies, human and institutional actors. Czarniawska (2004) uses the word "connection” suggesting that connecting is the central activity in organizing processes. Chia (2003) presents an argument for organizing as "worldmaking”. By world-making he means how organizing involves combining heterogeneous factors that all work to stabilize actions in time-space. Law (1994) makes a similar point in seeing organization as the heterogeneous mix of materials, technologies, texts and humans gathered into an entity, the formal organisation. In Law's terms a 'pure' social organisation would not last very long; it is through building a network of heterogeneous elements an object comes to be more or less stable. Such conceptualizations are powerful for understanding how different elements interact - or are made to interact - thus forming a stabilizing configuration.

Latour's (1987) work in Actor-Network Theory is particularly instructive for understanding how connecting processes unfold. Latour refers to actions such as enrolment, inscription, translation and mobilization, which are actions undertaken by some actors in order to secure the participation of other actors in the network. Actors, which Latour partly replaces with the term "actants" to emphasize the active role played by nonhuman as well as human actors, are constantly at work to add or remove other actors/actants to the network, thereby improving the chances of survival. Latour, whose work is draws some inspiration from Whitehead (1929), illustrates how his analytical framework works in explaining developments such as the Diesel engine and the Kodak camera.

Connectivity implies a relational way of understanding organization, where the nature of the connecting elements is not limited to the social, nor is it limited to the physical. An overriding principle is that of heterogeneity (Law, 1994), where elements from the social and the physical interact to produce and reproduce their connections. Connectivity is thus a process view that permits understanding of how various 
elements relate, and how their relating turns into network. The network feeds mainly on its own process of connecting. As some elements change or new elements enter, the configuration changes, which means that relations between other elements change. In this way, the configuration undergoes recurring processes of connecting and reconnecting.

Another principle, related to that of heterogeneity, is that of symmetry. For example, technology is related to human in such a way that it takes part in shaping human actors as participants in the organization, as much as human actors shape technology. Machines, for example, are not just considered machines in a technical sense, but also as elements that take part in shaping the elements - human and non-human - that are associated with the machines. Lindahl (2005:62), for example, who studied the effects of a company manufacturing and installing a 250 tonne machine, made the following observation:

"[...] the engine as a tool or a component in a rational construction process has to be replaced with a more totemistic image. The engine is not only a component among other components, although bigger, heavier and more complex. It carries the raison d'être of the company and of its employees. In this company, in this context, the engine makes the people engineers. “

The machine is perceived as an entity, just as people in contact with it are perceived as entities. What makes this an endogenous process view, however, is firstly that focus is on the relating as much as on entities, whereby the machine is seen to take part in shaping human actors connected to it. The analysis is directed toward how relations serve to co-create the entities that are related. Second, the characteristics of the entities are open, because the entities are in the making. What we "see" are labels, such as actor, machines or artefacts, whereas their "content" is forever open to definition and modification.

Connectivity, of which Actor-network theory is an example, is by all intents and purposes an endogenous view because the process resides in the connections that are 
formed and reformed ${ }^{1}$. Entification lies with connecting entities which are not assumed to take a final form, but, as pointed out above, are mere "open” entities, ready to take one changing characteristics as their relations change. A different level of entification takes place as certain constellations of entities take on names or labels may turn into "macro-actors", or "black boxes" (Latour, 1999). In much the same way that Czarniawska (1997; 2004), in her discussion of action nets, sees action nets as creating actors, the connecting gives shape to entities.

\section{Endogenous view 2: Process as recursive reproduction}

Organization may alternatively be seen as temporarily structured a state that is constantly in processes of construction and reconstruction, for which Feldman (2000) appropriately uses the term "ongoing accomplishments". Feldman uses the expression to point out how seemingly stabilised states are the result of painstaking processes with uncertain outcomes. The perspective of organization as engaging in a process of recursive reproduction owes much to works in sociology, notably by Giddens and Luhmann. Giddens developed his structuration theory on the basis that social systems exist through their continuous structuration in the course of time (Giddens, 1979:217). His structuration theory has influenced a number of works in organization theory (e.g. Bartunek, 1984; Ranson, Hinings and Greenwood 1980; Barley and Tolbert, 1997; Orlikowski and Yates, 2002). Giddens drew upon the work of Bourdieu, and his notion of habitus in particular. Bourdieu's conceptualization of habitus was as a generative principle, which lies at the basis of practices, but which is modified by those practices in turn. The principle, or habitus, is open to modification, but it is stable enough to serve as a basis for practices (Bourdieu, 1977). In a sense, habitus, although it is constantly under revision, is stable to the extent that it may be ascribed sets of characteristics. In a somewhat similar way, Giddens works from the idea of systems engaging in continuous structuration, where systems have structures, which are being modified through processes of structuration. Structures are semi stable stabilizing arrangements serving as bases of structuration.

\footnotetext{
${ }^{1}$ The external environment exists, but as a reservoir from which elements and
} relations are created, and not as a neutral, constant, determining factor. 
The relationship between structure and process is a recursive relationship, whereby they both take part in their mutual production. As mentioned above, Giddens (1979, 1984) points out the recursive character of social life, with structure being both the medium and the outcome of social practices. In other words, social practices take place due to structure, but they tend to reproduce or modify the structure in turn. This is what happens with events as well, in the sense that they take place within a structure, while also reproducing and modifying it.

A sociologist and organization writer who has given exclusive attention to the idea of recursive reproduction, is Niklas Luhmann (1995, 2000), whose autopoietic social systems theory is increasingly being drawn upon in organization and management studies (e.g. Bakken and Hernes, 2003; Seidl, 2005; Seidl and Becker, 2006). Luhmann works from an analytical distinction between structure and process interacting recursively with one another. Structure without process becomes a shell, just as process without structure becomes action without direction. This is why Luhmann does not treat process as isolated from structure, but considers structure and process as complementary terms (Luhmann 2000:340). For example, in the case of budgeting, the budget may be seen as structure, in the sense that budgets serve to bind activities in time and space. The binding provided by budgets cannot exist independently of the activities they bind, otherwise there could be no feedback into the budgeting processes. Therefore, in the absence of activity there is nothing to inform the budget, hence budget as a structure would not be able to reproduce itself. When process is viewed as recursive reproduction, the locus of entification resides with the structure, which may be seen as a temporary arrangement being produced by processes, on which processes feed in turn. Structures, if they are to act as bases for processes, need to exhibit some recognisability, which they sometimes do in the form of mechanisms, such as rules, budgets, plans or technology.

A common feature of studies, whether influenced by Giddens' structuration theory or by Luhmann's social systems theory, is a focus on the time dimension. Reproduction takes place with reference to past history, which is embedded in present structure. A recursive perspective of organization is thus in many ways a process perspective whereby a temporarily entified form of organization forms a basis for organizing processes. Current states of organization embodies the history of the past; events, 
experiences and structures that are inscribed into the present. The present state of organization forms a basis from which organizing processes are projected into the future. The present state does not influence the future in a determinist way, but works as a contingency, in the sense that it forms a horizon against which processes of organization are undertaken.

\section{Concluding notes}

The four interpretations of process discussed above and shown in table 1 below, do not represent the whole panoply of process perspectives in organization studies. They do, however, represent distinct “poles” around which much process thinking seems to gravitate.

The discussion of the four types of views shown scematically in table 1, suggests how the locus and the nature of entification differs between them. It suggests moreover that differences in locus of entification are considerable between the views. Differences between exogenous and endogenous view are particularly important. Exogenous views emphasize context, which is a spatial visualization of processes. According to en exogenous view, flows or programmes consist of actions framed by organizational contexts. Endogenous views, on the other hand, lend more emphasis to time, in the sense that entification takes place over time rather than space. In the case of connectivity, the process of relating creates entities over time, influencing the relations in turn. Process as recursive reproduction is perhaps even more time based, in the sense that structured states are assumed to embody the history, forming a basis for processes to come.

If this typification is accepted, it suggests that the question of locus of entification demands great care when performing organizational analysis. The typification suggests that it matters a lot whether, for example, process is assumed to be framed by an external context or whether the process is considered to be the forming of entities. An advantage of working with such a typification as a backdrop for analysis is that it may help analytic consistency to be upheld. It is open to question whether different views are reconcilable with one another in the sense that different view may be taken in the same analysis. 
Our paper started with a critique of the simple distinction between process and entity suggested by Van de Ven and Poole (2005). We think that the typification presented in this paper is a more nuanced distinction, and one that is better suited for organizational analysis. Still, what we have presented here remains coarse, and could benefit from further development and refinement.

\begin{tabular}{|c|c|c|}
\hline \multirow{3}{*}{$\begin{array}{l}\text { Exogenous } \\
\text { views }\end{array}$} & Process as flows & $\begin{array}{l}\text { Criss-crossing flows of multiple types. } \\
\text { Constitute the particularity and identity of the } \\
\text { organization. Entification taking place in what } \\
\text { is considered the “context” for the flows. }\end{array}$ \\
\hline & & \\
\hline & $\begin{array}{l}\text { Process as } \\
\text { programmes }\end{array}$ & $\begin{array}{l}\text { As formalized organizational problem solving } \\
\text { processes, they are constitutive of formal } \\
\text { organizations. Entification takes place, either } \\
\text { as programmes are correlated with factors in } \\
\text { the external environment, or they become } \\
\text { standardised and categorized under labels, } \\
\text { allowing them to travel. }\end{array}$ \\
\hline \multirow{2}{*}{$\begin{array}{l}\text { Endogenous } \\
\text { views }\end{array}$} & $\begin{array}{l}\text { Process as } \\
\text { connectivity }\end{array}$ & $\begin{array}{l}\text { A relational way of seeing organization, where } \\
\text { organization is seen as the unfolding of } \\
\text { relations between heterogeneous elements. } \\
\text { Entification lies with the connecting elements. }\end{array}$ \\
\hline & $\begin{array}{l}\text { Process as } \\
\text { recursive } \\
\text { reproduction }\end{array}$ & $\begin{array}{l}\text { Organization seen as unfolding through } \\
\text { reproduction around a relatively stable } \\
\text { evolving structure. Entification lies with semi } \\
\text { stable structures recursively implicated with } \\
\text { processes. }\end{array}$ \\
\hline
\end{tabular}

Table 1. Four types of process views 


\section{Bibliography}

Aldrich, Howard (1999) Organizations evolving. Thousands Oaks, CA: Sage.

Bakken, Tore and Tor Hernes (Eds.) (2003) Autopoietic organization theory: Drawing on Niklas Luhmann's Social Systems Perspective. Oslo: Abstrakt, Liber, Copenhagen Business School Press.

Bakken, Tore and Tor Hernes (2006) Organizing is both a verb and a noun: Weick meets Whitehead. Organization Studies 27(11):1599-1616.

Barley, Stephen R.; Tolbert, Pamela S. (1997). “Institutionalization and structuration: studying the links between institutions and actions”, in Organization Studies, 18(1), pp. 93-117.

Bartunek, Jean M. (1984). "Changing interpretive schemes and organizational restructuring: the example of a religious order”, in Administrative Science Quarterly, 29: pp. 355-372.

Bergson, Henri (1988) Matter and memory. New York: Zone Books.

Brunsson, Nils (2005) Mechanisms of hope. Stockholm: Liber.

Brunsson, Nils and Johan P. Olsen (1990). The reforming organization. London: Routledge.

Bourdieu, Pierre (1977). Outline of a theory of practice. Cambridge: Cambridge University Press.

Burns, Tom and Jeremy M. Stalker (1961) The management of innovation. London: Tavistock.

Czarniawska, Barbara (1997) Narrating the organization - dramas of institutional identity. Chicago: University of Chicago Press

Czarniawska, Barbara (2004) On time, space, and action nets. Organization 11(6):773-791.

Chia, Robert (1999) A 'Rhizomic' model of organizational change and

transformation: perspective from a metaphysics of change. British Journal of Management 10:209-227.

Chia, Robert (2003) Ontology: Organization as “world-making”. In R. Westwood and S. Clegg (Eds.) Debating organization. Malden, MA: Blackwell. 
DiMaggio, Paul J. and Walter W. Powell (1983) The iron cage revisited; institutional isomorphism and collective rationality in organizational fields. American Sociological Review 48:147-160.

Campbell, Donald T. (1969) Variation and selective retention in socio-cultural evolution. General Systems 14: 69-85.

Czarniawska, Barbara (1997) Narrating the organization - dramas of institutional identity. Chicago: University of Chicago Press

Czarniawska, Barbara (2004) On time, space, and action nets. Organization 11(6):773-791.

Czarniawska, Barbara and Tor Hernes (Eds.) Actor-network theory and organizing. (in press). Stockholm: Liber Ekonomi.

Elias, Norbert (1970). What is sociology? London: Hutchinson.

Feldman, Martha (2000) Organizational routines as a source of continuous change. Organization Science 11(6):611-629.

Feldman, Martha and Brian Pentland (2005) Organizational routines and the macroactor. In B. Czarniawska and T. Hernes (Eds.) Actor-Network theory and organizing. Stockholm: Liber.

Giddens, Anthony (1979). Central problems in social theory: Action, structure and contradiction in social analysis. London: Macmillan.

Giddens, Anthony (1984). The constitution of society. Cambridge: Polity Press.

Hannan, Michael T.; Freeman, John (1989). Organizational ecology. Cambridge, Mass.: Harvard University Press.

Hernes, Tor (2004) The spatial construction of organization. Amsterdam: John Benjamin.

Hernes, Tor (2007) Understanding organization as process - theory for a tangled world. London: Routledge (forthcoming).

Hernes, Tor and Gerhard Schjelderup (2005) En forklaring av stabilitetens dynamikk: Et rekursivt syn på dypstrukturer og strategisk endring. Nordiske Organisasjonsstudier 7(1):5-31.

James, William [1909](1996) A Pluralistic Universe. Lincoln, NE: University of Nebraska Press.

Latour, Bruno (1987) Science in action. Cambridge, Mass.: Harvard University Press. 
Latour, Bruno (1999). Pandora's hope - essays on the reality of science studies. Cambridge, Mass.: Harvard University Press.

Law, John (1994) Organizing modernity. Oxford: Blackwell.

Law, John (2004) After method - mess in social science research. Oxon: Routledge.

Lindahl, Marcus (2005) The little engine that could: On the "managing” qualities of technology. In B. Czarniawska and T. Hernes (Eds.) Actor-Network theory and organizing (50-66). Stockholm: Liber and CBS Press.

Luhmann, Niklas (1995) Social systems. Stanford: Stanford University Press.

Luhmann, Niklas (2000) Organisation und enscheidung. Opladen: Westdeutscher Verlag.

March, James G. (1981). "Footnotes to organizational change”. Administrative Science Quarterly 26, pp. 563-577.

March, James G. (1988) Decisions and organizations. Oxford: Blackwell.

March, James G.; Simon, Herbert A. (1958). Organizations. New York: John Wiley.

March, James G.; Olsen, Johan P. (1975). “The uncertainty of the past: organizational learning under ambiguity”. The European Journal of Political Research 3, pp. 14771.

Morgan, Glenn, Richard Whitley and Eli Moen (Eds.) (2005) Changing capitalisms? Internationalization, institutional change, and systems of economic organization. Oxford: Oxford University Press.

Orlikowski, Wanda J. and Joanne Yates (2002) It's about time: Temporal structuring in organizations. Organization Science 13(6):684-700.

Pettigrew, Andrew M. (1987) The management of strategic change. Basil Blackwell, Oxford.

Pettigrew, Andrew M. (1997) What is a processual analysis? Scandinavian Journal of Management 13(4):337-348.

Pettigrew, Andrew, Richard W. Woodman and Kim S. Cameron (2001). Studying organizational change and development: Challenges for future research. Academy of Management Journal 44(4):697-713.

Ranson, Stewart; Hinings, Bob; Greenwood, Royston (1980). “The structuring of organizational structures”, in Administrative Science Quarterly 20, pp. 1-17. 
Seidl, David (2005) Organizational identity and self-transformation - an autopoietic perspective. Aldershot: Ashgate.

Seidl, David and Kai Becker (Eds.) (2006) Niklas Luhmann and organization studies. Stockholm: Liber.

Smith, Adam [1776](1986). The wealth of nations. Harmondsworth: Pelican.

Styhre, Alexander (2004) Rethinking knowledge: A Bergsonian critique of the notion of tacit knowledge. British Journal of Management 15:177-188.

Tsoukas, Haridimos and Robert Chia (2002) On organizational becoming: rethinking organizational change. Organization Science 13(5):567-582.

Van de Ven, Andrew and Marshall Scott Poole (2005) Alternative approaches for studying organizational change. Organization Studies 26(9):1377-1404.

Weick, Karl E. (1977) 'Enactment processes in organizations' in B. Staw and G. R. Salancik (Eds.) New directions in organizational behavior, 267-300. Chicago, IL: St. Vlair Press.

Weick, Karl E. and Robert Quinn (1999) Organizational change and development. Annual Review of Psychology, 50: 361-386.

Weick, Karl E. (1995) Sensemaking in organizations. Thousand Oaks, Cal: Sage. Whitehead, Alfred North ([1929]1978). Process and reality. New York: The Free Press.

Whitehead, Alfred North (1938) Modes of thought. New York: The Free Press. 